
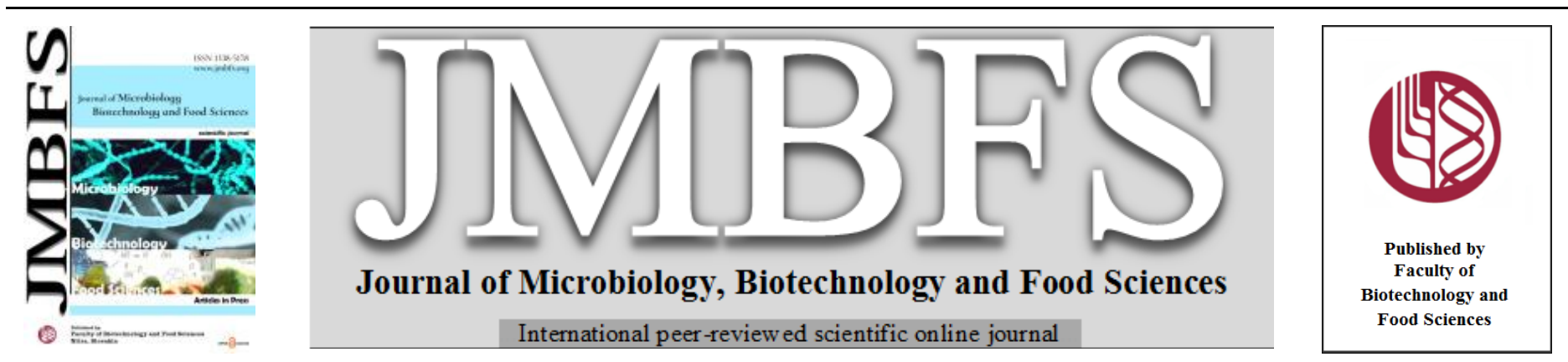

\title{
LANTIBIOTICS OF MILK ISOLATES: A SHORT REVIEW ON CHARACTERIZATION AND POTENTIAL APPLICATIONS
}

\author{
Vajid Nettoor Veettil ${ }^{1 *}$ and Vijaya Chitra $^{2}$
}

Address(es): ${ }^{1 *}$ Research Scholar, Department of Microbiology, Sree Narayana Guru College, 641105, K G Chavadi, Coimbatore, Tamil Nadu, India, +91 9605555029. ${ }^{2}$ Associate Professor, Sree Narayana Guru College, 641105, K G Chavadi, Coimbatore, Tamil Nadu, India.

*Corresponding author: vajidnv@gmail.com

https://doi.org/10.55251/jmbfs. 3702

\section{ARTICLE INFO}

Received 11. 9. 2020

Revised 14. 9. 2021

Accepted 21.9. 2021

Published 1. 2. 2022

Regular article OPEN $\partial_{\text {ACCESS }}$

\begin{abstract}
Milk, due to its high nutritional content, is an excellent medium for supporting growth of diverse group of microorganisms, many of which produce beneficial compounds like bacteriocins. Class I bacteriocins, called lantibiotics, are ribosomally synthesized, post-translationally modified peptides containing unusual amino acids, such as dehydrated and lanthionine residues with antibacterial activities. Bacterial strains isolated from milk and dairy products produce a range of lantibiotics which can employed for development of food preservatives, flavor enhancers and as alternate treatment strategies for multi drug resistant bacterial pathogens. The diverse category of lantibiotics from milk isolates include well characterized prototypes like nisin to newer peptides yet to be studied. In this review, details of most prominent lantibiotics obtained from milk isolates have been presented with special focus on applications of these lantibiotics in therapeutics and food.
\end{abstract}

Keywords: Lantibiotics, milk, bacterial strains, antimicrobials, multi drug resistant pathogens

\section{INTRODUCTION}

The diverse microbial populations in milk apart from contributing to the desirable traits of various milk-derived products produce a range of antimicrobial compounds that confer preservative action. Ribosomally synthesized antibacterial peptides (bacteriocins) produced by inherent microflora form an important class of bioactive compounds in milk (Leroy and De Vyust, 2010). These compounds have gained considerable interest in the recent past owing to their inhibitory action against a wide range of pathogenic microorganisms (Farkas-Himsley 1980; Sahl and Bierbaum, 2008). Amongst the various classes of bacteriocins, the Class I bacteriocins, called lantibiotics, have been the focus of many biomedical research groups due their ability to aggressively destroy target cells and multiple modes of action (Cotter et al., 2005b; Cavera et al., 2015). Lantibiotics are small $(<5 \mathrm{kDa}$, 19-38 amino acids) heat-stable bacteriocins which are synthesized by posttranslational modifications to include the unusual thioether amino acids lanthionine (Lan) and methyllanthionine (MeLan) (McAuliffe et al., 2001; Cotter et al., 2005a; Dufour et al., 2007). Since the discovery of the prototype lantibiotic, Nisin in 1928 (Rogers and Whittier, 1928), more than 10 different kinds of lantibiotics have been characterized till date. These peptides are largely produced by Gram positive bacteria which include species like Lactobacillus, Leuconostoc and Enterococcus that are constitute the dominant microflora of milk and other dairy products. Several lantibiotics with potential applications in as antimicrobials in therapeutics, food industry and agriculture have also been reported to be produced by many strains of phylum Actinobacteria (Gomes et al., 2017). Also, a lantibiotic called pseudomycoicidin has been heterologously produced in E.coli (Basi-Chipalu et al., 2015)

The major aspect that distinguishes lantibiotics from other lanthionine containing peptides is their antimicrobial action, hence the name lantibiotic (Lanthionine containing antibiotics). In recent times, overuse of antibiotics has led to the emergence of multidrug resistant bacteria, thereby prioritizing research on the search for alternative treatment strategies. Moreover, antibiotics present several drawbacks such as inhibition of normal microbiota and diverse side effects (Iannitti and Palmieri, 2010). In this aspect, lantibiotics with their unique structural make up and distinctly different mechanisms of action constitute an emerging class of natural products which are promising alternatives to currently used antibiotics (Sahl and Bierbaum, 2008; Cavera et al., 2015). Lantibiotics are generally inhibitory to Gram positive bacteria, many of which are precarious human pathogens such as methicillin resistant Staphylococcus aureus (MRSA), vancomycin intermediate $S$. aureus (VISA), vancomycin resistant enterococci
(VRE), Streptococcus pneumoniae and Clostridium difficile, amongst others (Cotter et al., 2013). This feature makes them suitable for use in human and veterinary medicine and also in the pharmaceutical industry (Dischinger $\boldsymbol{e t}$ al., 2014).

Milk forms an important component of diet of majority of the population globally, particularly in the Indian subcontinent. The natural nutrient rich composition of milk makes it an excellent medium to support survival of microorganisms which include lantibiotic producing bacterial strains also. Study of lantibiotics from these bacterial strains will provide an important insight in the use of milk and dairy products as effective mediums for multistrain probiotic cultures and of milk derived lantibiotics in therapeutic applications. The objective of this study is to provide collated details of important lantibiotics from bacterial strains isolated from milk and the applications of these lantibiotics in food industry and therapeutics.

\section{GENERAL PROPERTIES OF LANTIBIOTICS}

Till date, over a 100 different types of lantibiotics have been discovered and characterized and have been exhaustively reviewed (McAuliffe $\boldsymbol{e t}$ al., 2001; Wiley and van der Donk, 2007; Basi- Chipalu, 2016) Based on their biosynthetic pathways (Willey and van der Donk, 2007), lantibiotics are classified in 4 classes: class I lantibiotics are those modified by two separate enzymes, a LanB (dehydratase) and LanC (cyclase); class II are modified by a single LanM enzyme with both dehydratase and cyclase activity (Siezen $\boldsymbol{e t}$ al., 1996). Class III and class IV are designated as lanthipeptides as they have no or weak antimicrobial activities and instead they perform morphogenetic activities and signaling functions for the producer cells (Willey and Gaskell, 2011). The prominent lantibiotics in milk isolates mostly belong to Class I category and few of them belong to Class II. Lantibiotics are synthesized as inactive prepeptides which are later converted to active peptides by extensive post translational modifications. Structurally, the most distinguishing feature of lantibiotics is presence of a high proportion of unusual amino acids, including the thioether amino acids Lan and MeLan and a number of dehydrated amino acids, such as the K,L-unsaturated amino acids Dha and Dhb, which are formed by sequence-specific dehydration of serine and threonine respectively during post translational modifications. Interaction of double bond in Dha and the thiol (-SH) group of a neighbouring cysteine residue results in formation of thioether Lan and MeLan. Hence presence of these intramolecular bridges makes lantibiotics polycyclic structures containing a number of Lan rings (Ingram, 1969). 
Lantibiotics are inhibitory to Gram-positive bacteria but are ineffective against Gram-negative bacteria, probably due to the outer membrane present in Gram negative bacteria that prevents entry of lantibiotic into the cell (Castiglione $\boldsymbol{e t}$ al., 2008). Although the bactericidal action is by different mechanisms (Asaduzzaman and Sonomoto, 2009) the primary mode of action of lantibiotics is based on either pore formation and/or inhibition of peptidoglycan synthesis (Brötz et al., 1998) Destruction of target cells by pore formation has been well studied in Nisin (Wiedemann et al., 2001) and lacticin $3147 \mathrm{~b}$ and other lantibiotics by gallidermin and epidermin (Bonelli et al., 2006). The insertion of lantibiotic on to the membrane of the target cells is mediated by lipid II in the cell membrane (van Heusden et al., 2002), which also stabilizes the resulting pores (Breukink $\boldsymbol{e t}$ al., 1999; Wiedemann et al., 2001). Following pore formation, cytoplamic contents and ions leak out of the cells thereby leading to collapse of the bacterial cell wall and death. Lan rings in lantibiotics such as nisin, mersacidin and planosporicin also bind to lipid II molecule in the cell wall and displace it. This causes accumulation of peptidoglycan precussors inside the cell leading to inhibition of peptidoglycan syhthesis (Hasper et al., 2006; Castiglione et al., 2007). It has been also observed that the lantibiotic nukacin ISK-1 is bacteriostatic rather than bactericidal, which is brought about by the reduction in the width of the cell wall leading to incomplete formation of the septum during cell division and thus inhibiting growth (Assaduzzaman and Sonomoto, 2009).

\section{LANTIBIOTIC PRODUCING BACTERIAL ISOLATES IN MILK}

Milk in healthy animals is sterile but becomes colonized thereafter by microorganisms from a variety of sources such as animal skin, water, air, milking equipment, soil and other sources (Vacheyrou $\boldsymbol{e t}$ al., 2011). Lactic acid bacteria (LAB), a group of bacteria which ferment lactose to lactate, make up the dominant population in milk from various animals and human. The most common LAB genera in milk include Lactococcus, Lactobacillus, Leuconostoc, Streptococcus and Enterococcus. Apart from LAB, bacterial strains of other genera such as Staphylococcus, Micrococcus, Microbacterium, Coliforms and Bacillus are commonly found (Quigly $\boldsymbol{e t}$. al., 2012). Many of these strains from raw milk produce are capable of producing putative bacteriocin-like compounds which have been shown to be active against human pathogens such as L. monocytogenes, Staph. aureus, C. tyrobutyricum, C. sporogenes, Ent. faecalis, Ent. faecium and Ent. durans (Alegría et al., 2010; Ortolani et al., 2010; Perin et al., 2012). A consolidated list of lantibiotic producing milk isolates have been given in Table 1. Amongst the lactic acid bacteria isolated from mik and dairy products, Lactococcus lactics produces two important lantibiotics nisin and lacticin (Piard et al., 1993; Ryan et al., 1996; Rodriguez et al., 2000). Nisin from L. lactis isolated from milk has been shown to be inhibitory against $L$. monocytogenes as well as other pathogens including E. coli and Staphylococcus spp. (Bravo et al., 2009; Alegría et al., 2010; Ortolani et al., 2010; Cosentino et al., 2012; Perin et al., 2012). Lactobacillus plantarum isolated from milk and milk products such as cheese and kefir has been reported to produce plantaricin C and plantaricin W (Turner et al., 1999; Holo et al., 2001; Todorov, 2008). Other lactic acid bacteria producing lantibiotics include Enterococcus feacalis (Booth et al., 1996; Nes et al., 2014), Streptococcus thermophilus (Gul et al., 2012) and Streptococcus macedonicus (Georgalaki et al., 2002; Georgalaki et $\boldsymbol{a l . , 2 0 1 3 )}$ which are inhibitory agains many pathogenic microorganisms and microbes causing food spoilage. As research advances, discovery of new strains adds on to the already existing list of lantibiotic producing lactic acid bacteria. One such strain, Streptococcus bovis HJ50 has been isolated from milk and the lantibiotic produced by the strain has been named bovicin HJ50 (Xiao et al., 2004).

Table 1 Lantibiotic producing bacterial strains isolated from milk and dairy products

\begin{tabular}{lcc}
\hline Bacterial strain & Lantibiotic & Reference \\
\hline Lactococcus lactis & NisinA & Gross \& Morell (1971) \\
& Nisin Z & de Vos (1993) \\
& Lacticin 3147 & Ryan et al. $(1996)$ \\
Lactobacillus plantarum & Lacticin 481 & Piard et al.(1993) \\
& Plantaricin C & Turner et al. (1999) \\
Enterococcus feacalis & Plantaricin W & Holo et al. $(2001)$ \\
Streptococcus macedonicus & Cytolysin & Booth et al. $(1996)$ \\
Streptococcus bovis & Macedocin & Georgalaki et al. $(2002)$ \\
Non aureus Staphylococci & Bovicin HJ50 & Xiao et al. $(2004)$ \\
(NAS) & Type 1 & \\
& lantibiotics; nisin & Carson et al. $(2017)$ \\
\hline & homologues & \\
\hline
\end{tabular}

Apart from lactic acid bacteria, lantibiotic production has also been reported in few strains of non- aureus Staphylococci (NAS) isolated from bovine milk. In a recent study by Carson et al., (2017) presence of bacteriocin clusters in whole genome of 441 NAS bovine milk isolates was determined by genome mining tools, BLAST, and comparison of genomes of closely related NAS isolates. Type 1 lanthipeptides producing gene clusters were identified in $S$. capitis, S. epidermidis and $S$. equorum by comparison with known lantibiotic gene clusters (Carson $\boldsymbol{e}$ al., 2017). This indicates that using genome mapping tools and BLAST searches, new novel bacterial strains and lantibiotics can be identified more rapidly and accurately. Almost all the lantibiotics characterized till date are produced by Gram positive bacterial strains (Nes and Tagg, 1996) and this holds true for lantibiotics of milk isolates. There are no reports of lantibiotic produced by Gram negative species in milk and dairy products.

\section{PROMINENT LANTIBIOTICS OF MILK AND DAIRY ISOLATES}

Lantibiotics from strains isolated from milk are particularly interesting, considering that most of the inherent bacterial strains in milk and milk derived products have GRAS (Generally Regarded As Safe) status. In this section, a brief overview of the structure, characterization, genetics and mode of action of prominent lantibiotics produced by bacterial strains isolated from milk and dairy products have been discussed. A snapshot of properties of these lantibiotics has been given in Table 2

\section{Nisin}

Nisin was accidentally discovered in 1928 in fermented milk cultures and commercially marketed in England in 1953 by Aplin \& Barrett as an antimicrobial agent (Rogers and Whittier, 1928; Delves-Broughton et al., 1996). Initially called as 'Group N (streptococci) inhibitory substance' in 1947, it is the only bacteriocin that has been approved by the World Health Organization for use as a food preservative since 1969 . Specifically, in 1983 it was added to the positive list of food additives as E234 in Europe in 1983 and in 1988 it received FDA approval as a GRAS (generally recognised as safe) substance (De Vuyst and Vandamme, 1994; Cotter et al., 2005b; Sobrino-López and Martín-Belloso, 2008). At present it is available as a commercial formulation called Nisaplin manufactured by Danisco and is widely used in food industry as a natural biopreservative for different types of foods (de Arauz et al., 2009). Nisin is naturally produced by food-grade strains of Lactococcus lactis subsp. lactis and non-food Streptococcus uberis. Till date, 8 natural variants (A, Z, F, Q, U, U2, and $\mathrm{H} \& \mathrm{P})$ and around 10 bioengineered variants of nisin have been elucidated (Shin et al., 2017). These variants differ not only in amino acid composition but also in solubility and diffusion characteristics (Lubelski et al., 2008; de Aruaz et al., 2009). Of these variants, nisin A, Z, F and Q belong to L. lactics isolated from milk and dairy products.

Structure of nisin was elucidated in 1971 and it is a single peptide composed of 34 amino acid residues, with a molecular mass of $3.5 \mathrm{kDa}$. Nisin belongs to the class I bacteriocins (type A lantibiotics). It is heat stable and particularly active at low $\mathrm{pH}$ (Liu and Hansen, 1990). It was also reported that the ring structure in nisin (ring $\mathrm{A}$ in nisin $\mathrm{A}$ and $\operatorname{ring} \mathrm{C}$ in nisin $\mathrm{Z}$ ) was important for its biological activity i.e. inhibition of bacterial growth and inhibition of spore germination (McAuliffe et al., 2001). Opening of the ring structures by hydrolytic cleavage or replacement of rings by disulphide bonds lead to loss of activity (Rollema et al., 1996; van Kraaji et al., 2000).

Nisin displays a broad spectrum of activity against different Gram-positive bacteria and inhibits outgrowth of spores of bacilli and clostridia primarily through pore formation in the target cell wall (McAuliffe et al., 2001). This attribute makes is an excellent biopreservative and even as a therapeutic agent in pharmaceutical, veterinary and health care products (de Arauz et al., 2009). Examples include the inhibition of Bacillus spp., Clostridium spp. and Staphylococcus aureus including MRSA (methycillin resistant Stap. aureus) and Enterococci including VRE (vancomycin resistant enterococci) (Field et al., 2015). The theraupeutic potentia of nisin also extends to other clinical frontiers such as oral health, cancer and mastitis where studies have shown positive outcomes with nisin (Shin et al., 2017; Małaczewska and Kaczorek-Lukowska, 2021).

Despite proven effects, several limitations still hinder the use of nisin in various applications. Its low solubility at neutral $\mathrm{pH}$, its protease sensitivity, sensitivity and inhibition by nisin non- resistance strains in milk and milk products prevents its widespread applications (Bhatti et al., 2004; Sobrino-López and MartínBelloso, 2008). Also, resistance towards nisin by the target bacteria may compromise its efficacy. Resistance to nisin often appears after direct exposure to a low level of lantibiotic or as part of an adaptive response to another stress and is in tandem with changes in membrane charge and fluidity, cell wall thickness and charge, and combinations thereof (Cotter et al., 2005b). The use of bioengineered variants can be a solution to overcome these shortcomings. 
Table 2 Properties of prominent lantibiotics from milk isolates

\begin{tabular}{|c|c|c|c|c|}
\hline Lantibiotic & Size & $\begin{array}{c}\text { Molecular } \\
\text { weight }\end{array}$ & Mode of action & Application \\
\hline Nisin & 34 amino acids & $3.5 \mathrm{kDa}$ & Pore formation in target cells & $\begin{array}{ll}- & \text { Food preservative } \\
- & \text { Biomedical applications }\end{array}$ \\
\hline Lacticin 3147 & 59 amino acids & $6.1 \mathrm{kDa}$ & Pore formation in target cells & $\begin{array}{ll}- & \text { Treatment of mastitis } \\
- & \text { Cheese processing }\end{array}$ \\
\hline Lacticin 418 & 27 amino acids & $2.9 \mathrm{kDa}$ & $\begin{array}{l}\text { Inhibition of peptidoglycan } \\
\text { synthesis of target cells }\end{array}$ & $\begin{array}{l}\text { Antilisterial biopreservative } \\
\text { for dairy products }\end{array}$ \\
\hline Macedocin & 26 amino acids & $2.8 \mathrm{kDa}$ & $\begin{array}{l}\text { Inhibition of peptidoglycan } \\
\text { synthesis of target cells }\end{array}$ & $\begin{array}{ll}- & \text { Flavor enhancer in cheese } \\
\text { - } & \text { Biopreservative }\end{array}$ \\
\hline $\begin{array}{l}\text { Plantaricin C } \\
\text { Cytolysin }\end{array}$ & $\begin{array}{l}27 \text { amino acids } \\
\text { Not available }\end{array}$ & $\begin{array}{l}\text { Not available } \\
\text { Not available }\end{array}$ & $\begin{array}{c}\text { Pore formation in target cells } \\
\text { Hemolytic }\end{array}$ & $\begin{array}{l}\text { Not available } \\
\text { Not available }\end{array}$ \\
\hline Bovicin HJ50 & 58 amino acids & $3.4 \mathrm{kDa}$ & $\begin{array}{l}\text { Cell membrane } \\
\text { permeabilisation }\end{array}$ & Not available \\
\hline
\end{tabular}

\section{Lacticin 3147}

Lacticin 3147 is a two-component lantibiotic produced by natural dairy isolates such as L. lactis subsp. lactis DPC 3147 and L. lactis IFPL 105 (Guinane et al., 2005). It is very heat stable, broad-spectrum lantibiotic that is active over a wide $\mathrm{pH}$ range against several Gram-positive bacteria, including food spoilers (e.g. Clostridium spp.), food pathogens (e.g. L. monocytogenes, Staph. aureus, and Bacillus cereus) and clinical pathogens (e.g. vancomycin resistant Enterococci) (Leroy and De Vuyst, 2010). Lacticin 3147 consists of two peptide chains viz. Ltn A1, 30 amino acids, $3.3 \mathrm{kDa}$ and LtnA2, 29 amino acids, $2.8 \mathrm{kDa}$. Post translationally, Serine to D-alanine conversion has been reported in both peptides of lacticin 3147 and it has been postulated that the broad antimicrobial inhibitory spectrum of lacticin 3147 is due to these D-alanine residues (Ryan et al., 1999).

Like nisin, lacticin 3147 also destroys target cells by formation of transmembrane pores and this is enhanced when target cells are energised. The pores formed by lacticin 3147 were shown to be selective for ions and not larger compounds such as ATP. Loss of ions via pores results in immediate dissipation of the energy and hydrolysis of internal ATP leading to cell death (McAuliffe et al., 2001). The broad range of antibacterial activity and lytic effects on related genera makes lacticin 3147 an excellent candidate for development of commercial products for various food related applications. Studies have shown that lacticin 3147 effectively inhibits growth of Listeria monocytogenes on cheese surface and hence can be developed as a bioprotective strain for the control of $L$. monocytogenes, a common dairy contaminant (O'Sullivan $\boldsymbol{e t}$ al., 2006). The high heat stability enhances its use in spray dried formulations and a lacticin 3147-based powder has successfully been evaluated as an antilisterial biopreservative for dairy products (Morgan $\boldsymbol{e}$ al., 2001; Guinane et al., 2005). Lacticin 3147 has also been studied in the treatment of bacterial mastitis and staphylococcal and enterococcal infections including VRE (Lawton et al., 2007; Piper et al., 2009).

\section{Lacticin 481}

Lacticin 481 is produced by several strains of Lactococcus lactis namely L. lactis CNRZ481 and L. lactis ADRIA85LO30 (Piard et al., 1993; van den Hooven $\boldsymbol{e}$ al., 1996). Unlike nisin and lacticin 3147 , which are broad-spectrum bacteriocins, lacticin 481 is a medium-spectrum bacteriocin that is mainly active towards clostridia and LAB (Guinane et al., 2005). This lantibiotic is made up of 27 amino acids and is $2.9 \mathrm{kDa}$ in size and belongs to class II lantibiotic group. Structurally, Lacticin 481 is quite distinct and contains the unusual $\alpha, \beta$-unsaturated amino acid dehydrobutyrine and the uncommon thioether-bridging residues lanthionine and 3-methyllanthionine, giving it an unusual bridging pattern (van den Hooven et al., 1996). The primary mode of action of lacticin 481 is by inhibition of peptidoglycan synthesis of target cells (Wiley and van der Donk, 2007). In fact, lacticin 481 is not very effective on pathogenic bacteria but can inactivate pathogens in combination with physicals methods such as high-pressure treatments (Rodriguez et al., 2005). The primary application of this lantibiotic is in dairy industry where lacticin 481-producing strains have been applied to prevent the growth of detrimental bacteria, such as C. tyrobutyricum (Thuault et al., 1991) and non-starter LAB (O'Sullivan et al., 2003) in dairy products. Also, it has been seen that lacticin 481-mediated lysis of certain Lactobacillus strains in cheese led to an increase flavor formation through the release of aminopeptidases (Garde $\boldsymbol{e t}$ al., 2007) and esterases (Ávila et al., 2007).

\section{Macedocin}

Another member of the lacticin 481 group of lantibiotics is macedocin which is produced by Streptococcus macedonicus ACA-DC 198 (Georgalaki et al., 2002; Georgalaki et al., 2010). Streptococcus macedonicus is a dairy streptococcus isolated from Greek Kasseri cheese (De Vuyst and Tsakalidou, 2008) Macedocin is composed of 26 amino acids with a molecular mass of $2.8 \mathrm{kDa}$. It is active at $\mathrm{pH}$ values between $\mathrm{pH} 4$ and 9 and it is relatively heat stable. Slow inactivation of this lantibiotic occurs in the presence of rennet (Georgalaki $\boldsymbol{e t}$ al. 2002). The antagonistic activities of macedocin suggest potential to combat spoilage and late loss in hard and semi-hard cheeses. Several macedocin producing strains displayed antibacterial activity towards C. tyrobutyricum and Propionibacterium freudenreichii subsp. shermanii (Georgalaki et al., 2000; Lombardi et al., 2004). Apart from that, macedocin also inhibits food spoilage bacteria such as Bacillus, pathogenic strains such as Listeria and a broad spectrum of LAB, suggesting a role for macedocin-producing strains as food starter cultures (De Vuyst and Tsakalidou, 2008). Biotherapeutic applications have not been reported for macedocin so far.

\section{Plantaricins}

Plantaricins are another group of lantibiotics that are produced by Lactobacillus plantarum, a common milk isolate (Todorov, 2009). Although they remain as the least characterized of the milk lantibiotics, plantaricin $\mathrm{C}$ and plantaricin $\mathrm{W}$ have been studied in certain aspects (Turner et al., 1999; Holo et al., 2001). Plantaricin $\mathrm{C}$ is produced by L. plantarum LL441 isolated from Cabrales cheese (Gonzalez et al., 1994). It was identified as a lantibiotic by Turner et al. in 1999, who also elucidated the structure of this lantibiotic. Plantaricin $\mathrm{C}$ is a 27 amino acid peptide with a linear $\mathrm{N}$ - terminal end and a globular $\mathrm{C}$-terminus, making it structurally similar to lacticin 481(Turner et al., 1999). Like nisin, plantaricin $C$ inactivates bacterial strains by formation of pores in the cytoplasmic membrane leading to the dissipation of the proton motive force and the release of intracellular molecules (i.e., glutamate and ATP) in sensitive cells (Gonzalez et al., 1996). However, it has been seen that plantaricin $\mathrm{C}$ also has an effect on the peptidoglycan layer in Lactobacillus fermentum in electron microscopy studies. In this aspect, plantaricin $\mathrm{C}$ resembles the mersacidin group of lantibiotics, which are known to inhibit peptidoglycan synthesis.

Plantaricin W is produced by the strain Lactocbacillus plantarum LMG 2379 (Holo et al., 2001) and is a two component peptide. Although the structure this lantibiotic has not been determined, models predict the structure to have a central lanthionine with two overlapping thioether bridges close to $\mathrm{C}$-terminus, making the structure similar to Type A lantibiotics like nisin (Holo et al., 2001). Both of the peptides have intrinsic antimicrobial properties but do not work independently and require the complimentary action of their partner peptide (Ryan $\boldsymbol{e t}$ al., 1999 Holo et al., 2001). Considering the structural aspects, the mode of action of plantaricin $\mathrm{W}$ appears to be similar to nisin i.e. it probably inhibits bacteria by pore formation. Little is known about the applications of plantaricins, thereby making them good candidates for further research and development.

\section{Cytolysin}

Enterococcus faecalis, a culture prevalent in dairy products produces cytolysin which is the only lantibiotic-type enterocin currently known (Booth et al., 1996) Cytolysin is a two-peptide bacteriocin and both structural subunits contain lanthionine residues (Booth et al., 1996). Presence of two linear peptides makes it structurally different to other linear lantibiotics, such as nisins $\mathrm{A}$ and $\mathrm{Z}$ that consist of only one linear peptide. It is also different to the smaller and globular lantibiotics produced by Streptomycetes (de Vos et al., 1995; Sahl et al., 1995). Cytolysin is haemolytic and it is active against eukaryotic cells (erythrocytes) and Grampositive bacteria (Gilmore et al., 1994; Booth et al., 1996)

\section{Bovicin HJ50}

One of the latest lantibiotic discovered from milk isolate is bovicin HJ50. This lantibiotic is produced by Streptococcus bovis HJ50 isolated from raw milk (Xiao et al., 2004). Structurally, it is a 58 amino acid cationic peptide consisting of an Nterminal leader sequence of 25 amino acid and a C-terminal propeptide domain of 33 amino acid. It has two thioether bridges and a disulfide bridge with two modified threonine residues. The molecular mass was determined to be $3.4 \mathrm{kDa}$. 
Like most lantibiotics produced by lactic acid bacteria, bovicin HJ50 showed a narrow range of inhibiting activity and was inhibitory to only Gram positive bacterial strains. In inhibitory action was seen against Lactobacillus curvatus LTH1174, Bacillus subtilis AS1.1087, Bacillus megaterium AS1.941, M. flavus NCIB8166, Leuconostoc dextranicum 181 and Leuconostoc mesenteroides AS1.2, but it did not inhibit Listeria monocytogenes. The inhibitory action of bovicin HJ50 could be due to cell membrane permeabilisation of target strains. Applications of this new lantibiotic are yet to be studied.

\section{GENOMIC ASPECTS OF LANTIBIOTICS FROM MILK ISOLATES}

Genes that are involved in lantibiotic biosynthesis are arranged in clusters, on transposable elements (e.g. nisin), on host chromosome or on plasmids (e.g. lacticin 481) (Chatterjee $\boldsymbol{e t}$ al., 2005). Till date, the amino acid sequences and gene clusters of several lantibiotics have been characterized and it has been observed that there is significant heterogeneity in the propeptide compositions and in the order and orientation of their gene clusters (Seizen et al., 1996). At the genetic level lantibiotic gene cluster typically comprises of a structural gene (lanA) and other genes that code for proteins responsible for posttranslational modification of the prepeptide $(\operatorname{lan} \mathrm{B}$ and $\operatorname{lan} \mathrm{C}$, or $\operatorname{lan} \mathrm{M})$, proteolytic processing (lan $\mathrm{P})$, transport (lan $\mathrm{T})$, self immunity of the producer (lan I and lanEFG), and regulation of biosynthesis ( $\operatorname{lan} \mathrm{R}, \operatorname{lan} \mathrm{K}$, and $\operatorname{lan} \mathrm{Q})($ Guder et al., 2000; McAuliffe et al., 2001). Propeptide compositions and the order and orientation of gene clusters vary considerably amongst the lantibiotics described till (Siezen $\boldsymbol{e t}$ al. 1996). Also, not all lantibiotic producer strains differ in the complement of lan genes, which indicates considerable variety of posttranslational modifications made to the final peptide and differences in mechanisms of processing, immunity and regulation of the different lantibiotics (Bierbaum et al., 1996). The knowledge about the genomic make up of lantibiotics is very important for bioengineering these peptides in order to improve their antibacterial action resistant pathogens. GenBank accession numbers of prominent lantibiotics from milk isolates has been given in Table 3.

Table 3 Genetic sequences of prominent lantibiotics from milk isolates

\begin{tabular}{lcc}
\hline Lantibiotic & GenBank Accession Number & Reference \\
\hline Nisin A & HM219853 & Parapouli et al., 2013 \\
Nisin Z & $\underline{\text { X61144 }}$ & Mulders et al., 1991 \\
Lacticin 3147 & AE001272 & Ryan et al., 1996 \\
Lacticin 481 & WP_032489363 & Sahl et al., 1995 \\
Plantaricin W & AY007251 & Holo et al., 2001 \\
Macedocin & $\underline{\text { DQ835394 }}$ & Papadelli et al., 2007 \\
Bovicin HJ50 & AY173079 & Xiao et al.,2004 \\
\hline
\end{tabular}

\section{APPLICATIONS OF LANTIBIOTICS OBTAINED FROM MILK ISOLATES}

Lantibiotics have unique structural chemistry and post translational modifications, which confer many desirable properties such as broad spectrum of antibacterial activity, small size, low molecular weight, thermostability and resistance to most proteolytic enzymes. This makes them excellent candidates for development of a vast array of applications in areas of food and therapeutics. Over the years, numerous studies have been conducted to define new areas of applications of lantibiotics produced by strains commonly found in milk. The advantage of milkderived antibiotics lies in the fact that most of the strains are GRAS (generally regarded as safe) thereby addressing the safety aspects of these molecules. Also, since they are derived from milk microbes, milk can be employed as delivery system for use of lantibiotics either in food applications or as medicines.

\section{Food applications}

The broad spectrum antimicrobial activity of milk-isolate lantibiotics particularly against food borne pathogens has been useful in studying the use of these peptides as food preservatives. Since its discovery in 1928, nisin has been used for decades in the food industry and is the only FDA approved commercially produced lantibiotic. It is sold in more than 40 countries and was added to the positive list of food additives by the EU as additive number E234 (EEC 1983). Owing to its GRAS status, it has been used as an effective and safe food preservative in processed dairy products, canned fruits and vegetables (Delves-Broughton, 1990). Application of nisin or nisin-producing starter cultures has been well documented in cheese products to control spoilage bacteria and food-borne pathogens (Thomas and Delves-Broughton, 2001; Sobrino-López and Martín-Belloso, 2008). Inhibition of Clostridium tyrobutyricum by nisin producing L. lactis strains in hard and semihard cheeses prevents excess gas formation and formation of defective cheese due to late blowing. It has been also used to control Listeria sp. in whey and cheese (Samelis et al., 2003).

Apart from nisin, other lantibiotics of milk isolates have been evaluated for their preservative actions. Lacticin 3147-producing strain can work as biopreservatives for the control of L. monocytogenes in cheese, (O'Sullivan et al., 2006) or to inhibit clostridia that causes late loss (Martínez-Cuesta et al. 2010). Lacticin 3147producing dairy isolates can be employed as starters in cheese making (Coakley $\boldsymbol{e t}$ al., 1997; O'Sullivan et al., 2003). Since it is heat stable, a spray dried lacticin 3147-based powder formulation has successfully used as an antilisterial biopreservative for dairy products (Morgan et al., 2001; Guinane et al., 2005) Lacticin 481-producing $L$. lactis strains have been used as flavor enhancers in cheese processing (Garde et al., 2007; Ávila et al., 2007). Macedocin, produced by S. macedonicus is active against many food pathogens including Bacillus, Clostridium and Listeria, suggesting the potential of use of macedocin-producing strains as food starter cultures (De Vuyst and Tsakalidou, 2008). The biopreservative aspects of other milk lantibiotics that inhibit food pathogens can be further explored for food preservation.

\section{Biotherapeutic applications of lantibiotics}

Indiscriminate use of antibiotics has led to the emergence of multi drug resistant bacterial pathogens and this mandates the discovery of new antimicrobials. In this aspects lantibiotics offer great potential as antibiotic alternatives since their structure and chemical makeup is unique and unusual and most of these peptides have been studied to have broad spectrum activities against many Gram positive pathogens including methicillin resistant Staphylococcus aureus (MRSA) vancomycin intermediate $S$. aureus (VISA), vancomycin resistant enterococci (VRE), Streptococcus pneumoniae and Clostridium difficile, amongst others (Cotter et al., 2013). There are several reports on the in vitro potency of lantibiotics against nosocomial pathogens (Piper et al., 2009; Field et al., 2015). Recently, techniques such as LC-UV-MS dereplication coupled with bioautography have been used to identify new strains that produce lantibiotics such as microbisporicin which has commercial potential against antibiotic resistant strains (Carrano et al., 2015)

Biomedical applications of nisin have reviewed in details recently (Shin $\boldsymbol{e t}$ al., 2016). Nisin by itself or in combination with conventional antibiotics, such as vancomycin or ciprofloxacin has been shown to be effective against MRSA strains in several studies (Brumfitt et al., 2002; Dosler and Gerceker, 2011; Singh et al., 2013). In another study it was seen that nisin exhibited bactericidal effects against a diverse panel of Gram-positive bacteria, including MRSA, VRE and $S$ pneumoniae (Severina et al., 1998). In addition, a nisin producing L. lactis strain was shown to reduce the intestinal colonization of VRE in a mouse infection model (Millette et al., 2008). Nisin is also effective against biofilm formation on medical devices (Okuda et al., 2013) and formation of biofilm by MRSA Xen 31 strain (Ahire and Dicks, 2015). Since it is highly effective against Staphylococcus species, nisin also has the potential as a veterinary bactericidal agent particularly in the treatment of mastitis caused by Staphylococcus in dairy cows (Cao et al., 2007; Wu et al., 2007).

Apart from its efficacy against pathogens causing infectious diseases, nisin has several applications in oral health as an anticariogenic agent (Tong et al., 2010) and an anti-biofilm lantibiotic (Shin et al., 2015). The cytotoxic and tumerogenic properties of nisin specifically pertaining to skin cancer have also been studied and it was found that nisin inhibited tumerogenesis in in vivo models (Joo et al., 2012). Lacticin 3147 is the other lantibiotic of milk isolate that has been shown to have biotherapeutic potential. It has been studies in the treatment of bacterial mastitis and infection caused by Staphylococcus and enterococci including vancomycin resistant enterococci (VRE) and skin conditions like acne (Galvin $\boldsymbol{e t}$ al., 1999; Lawton et al., 2007). This indicates to the vast area of research still unexplored in the field of lantibiotics in biomedical applications.

\section{CONCLUSIONS AND FUTURE PROSPECTIVES}

Milk forms an important part of the diet of most of the population globally and is the chief source of nutrients for people of developing nations. In this aspect beneficial milk derived compounds are especially important as they can be incorporated easily into the dietary regime. As the list of lantibiotics produced by milk isolates continues to grow, it is evident that this group of antimicrobials is diverse in terms of their structure, genetics and mode of action. This provides scope for the discovery of new structural elements and functionalities and consequently, new applications, be it in the area of food preservation or as antimicrobials targeted towards more resistant pathogens. Genetic engineering and protein engineering can be exploited in the construction of novel lantibiotic variants with desirable traits. Database mining and PCR analysis of genomic DNA of milk isolates could be employed in discovery of new lantibiotics and extend the range of applications and development of alternatives for antimicrobial drugs.

\section{REFERENCES}

Ahire, J. J., \& Dicks, L. M. (2015). Nisin Incorporated With 2,3-Dihydroxybenzoic Acid in Nanofibers Inhibits Biofilm Formation by a Methicillin-Resistant Strain of Staphylococcus aureus. Probiotics and antimicrobial proteins, 7(1), 52-59. https://doi.org/10.1007/s12602-014-9171-5 
Alegría, A., Delgado, S., Roces, C., López, B., \& Mayo, B. (2010). Bacteriocins produced by wild Lactococcus lactis strains isolated from traditional, starter-free cheeses made of raw milk. International journal of food microbiology, 143(1-2), 61-66. https://doi.org/10.1016/j.ijfoodmicro.2010.07.029

Asaduzzaman, S.M., \& Sonomoto, K. (2009). Lantibiotics: Diverse activities and unique modes of action. Journal of Bioscience and Bioengineering, 107(5), 475487. https://doi.org/10.1016/j.jbiosc.2009.01.003

Ávila, M., Calzada, J., Garde, S., \& Nuñez, M. (2007). Lipolysis of semi-hard cheese made with a lacticin 481-producing Lactococcus lactis strain and a Lactobacillus helveticus strain. Dairy Science \& Technology, 87, 575-585. 10.1051/lait:2007035.

Basi-Chipalu, S., Dischinger, J., Josten, M., Szekat, C., Zweynert, A., Sahl, H. G., \& Bierbaum, G. (2015). Pseudomycoicidin, a Class II Lantibiotic from Bacillus pseudomycoides. Applied and environmental microbiology, 81(10), 3419-3429. https://doi.org/10.1128/AEM.00299-15

Basi-Chipalu, Shradha. (2016). A Review: Lantibiotics, a Promising Antimicrobial Agent. Journal of Institute of Science and Technology. 21. 119 10.3126/jist.v21i1.16063

Bhatti, M., Veeramachaneni, A., \& Shelef, L. A. (2004). Factors affecting the antilisterial effects of nisin in milk. International journal of food microbiology, 97(2), 215-219. https://doi.org/10.1016/j.ijfoodmicro.2004.06.010 Bierbaum, G., Szekat, C., Josten, M., Heidrich, C., Kempter, C., Jung, G., \& Sahl, H. G. (1996). Engineering of a novel thioether bridge and role of modified residues in the lantibiotic Pep5. Applied and environmental microbiology, 62(2), 385-392. https://doi.org/10.1128/AEM.62.2.385-392.1996

Booth, M. C., Bogie, C. P., Sahl, H. G., Siezen, R. J., Hatter, K. L., \& Gilmore, M S. (1996). Structural analysis and proteolytic activation of Enterococcus faecalis cytolysin, a novel lantibiotic. Molecular microbiology, 21(6), 1175-1184. https://doi.org/10.1046/j.1365-2958.1996.831449.x

Bravo, D., Rodríguez, E., \& Medina, M. (2009). Nisin and lacticin 481 coproduction by Lactococcus lactis strains isolated from raw ewes' milk. Journal of dairy science, 92(10), 4805-4811. https://doi.org/10.3168/jds.2009-2237

Brötz, H., Josten, M., Wiedemann, I., Schneider, U., Götz, F., Bierbaum, G., \& Sahl, H. G. (1998). Role of lipid-bound peptidoglycan precursors in the formation of pores by nisin, epidermin and other lantibiotics. Molecular microbiology, 30(2), 317-327. https://doi.org/10.1046/j.1365-2958.1998.01065.x

Brumfitt, W., Salton, M. R., \& Hamilton-Miller, J. M. (2002). Nisin, alone and combined with peptidoglycan-modulating antibiotics: activity against methicillinresistant Staphylococcus aureus and vancomycin-resistant enterococci. The Journal of antimicrobial chemotherapy, 50(5), 731-734. https://doi.org/10.1093/jac/dkf190

Cao, L. T., Wu, J. Q., Xie, F., Hu, S. H., \& Mo, Y. (2007). Efficacy of nisin in treatment of clinical mastitis in lactating dairy cows. Journal of dairy science, 90(8), 3980-3985. https://doi.org/10.3168/jds.2007-0153

Carson, D. A., Barkema, H. W., Naushad, S., \& De Buck, J. (2017). Bacteriocins of Non-aureus Staphylococci Isolated from Bovine Milk. Applied and environmental microbiology, 83(17),

e01015-17.

https://doi.org/10.1128/AEM.01015-17

Castiglione F, Cavaletti L, Losi D, et al. A novel lantibiotic acting on bacterial cel wall synthesis produced by the uncommon actinomycete Planomonospora sp. Biochemistry. 2007 May;46(20):5884-5895. DOI: 10.1021/bi700131x.

Castiglione, F., Lazzarini, A., Carrano, L., Corti, E., Ciciliato, I., Gastaldo, L. Candiani, P., Losi, D., Marinelli, F., Selva, E., \& Parenti, F. (2008). Determining the structure and mode of action of microbisporicin, a potent lantibiotic active against multiresistant pathogens. Chemistry \& biology, 15(1), 22-31. https://doi.org/10.1016/j.chembiol.2007.11.009

Cavera, V. L., Arthur, T. D., Kashtanov, D., \& Chikindas, M. L. (2015) Bacteriocins and their position in the next wave of conventional antibiotics. International journal of antimicrobial agents, 46(5), 494-501. https://doi.org/10.1016/j.ijantimicag.2015.07.011

Chatterjee, C., Paul, M., Xie, L., \& van der Donk, W. A. (2005). Biosynthesis and mode of action of lantibiotics. Chemical reviews, 105(2), 633-684. https://doi.org/10.1021/cr030105v

Coakley, M., Fitzgerald, G., \& Ros, R. P. (1997). Application and evaluation of the phage resistance- and bacteriocin-encoding plasmid pMRC01 for the improvement of dairy starter cultures. Applied and environmental microbiology, 63(4), 1434-1440. https://doi.org/10.1128/AEM.63.4.1434-

$\underline{1440.1997}$

Cosentino, S., Fadda, M.E., Deplano, M., Melis, R., Pomata, R., \& Pisano. M.B (2012). Antilisterial activity of nisin-like bacteriocin-producing Lactococcus lactis subsp. lactis isolated from traditional sardinian dairy products. Journal of Biomedicine and Biotechnology,

2012

2012:376428. https://doi.org/10.1155/2012/376428

Cotter, P. D., Hill, C., \& Ross, R. P. (2005a). Bacteriocins: developing innate immunity for food. Nature reviews. Microbiology, 3(10), 777-788. https://doi.org/10.1038/nrmicro1273

Cotter, P. D., Hill, C., \& Ross, R. P. (2005b). Bacterial lantibiotics: strategies to improve therapeutic potential. Current protein \& peptide science, 6(1), 61-75. https://doi.org/10.2174/1389203053027584
Cotter, P. D., Ross, R. P., \& Hill, C. (2013). Bacteriocins - a viable alternative to antibiotics?. Nature reviews. Microbiology, 11(2), 95-105. https://doi.org/10.1038/nrmicro2937

de Arauz, L.J., Jozala, A.F., Mazzola, P.G., \& Penna, T.C.V. (2009). Nisin biotechnological production and application: a review. Trends in Food Science and Technology,20(3-4), 146-154.

de Vos, W. M., Kuipers, O. P., van der Meer, J. R., \& Siezen, R. J. (1995) Maturation pathway of nisin and other lantibiotics: post-translationally modified antimicrobial peptides exported by gram-positive bacteria.Molecular microbiology, 17(3), 427-437. $\quad$ https://doi.org/10.1111/j.1365 2958.1995.mmi 17030427.x

De Vuyst, L., \& Vandamme, E.J. (1994).Bacteriocins of lactic acid bacteria: microbiology,genetics, and applications. Blackie Academic \& Professional, London, UK.

De Vuyst, Luc., \& Tsakalidou, Effie. (2008). Streptococcus macedonicus, a multifunctional and promising species for dairy fermentations. International Dairy Journal, 18, 476-485. 10.1016/j.idairyj.2007.10.006.

Delves-Broughton, J. (1990). Nisin and its uses as a food preservative. Food Technology, 44(11), 100-117.

Delves-Broughton, J., Blackburn, P., Evans, R. J., \& Hugenholtz, J. (1996) Applications of the bacteriocin, nisin. Antonie van Leeuwenhoek, 69(2), 193-202. https://doi.org/10.1007/BF00399424

Dischinger, J., Basi Chipalu, S., \& Bierbaum, G. (2014). Lantibiotics: promising candidates for future applications in health care. International journal of medical microbiology: IJMM, 304(1), 51-62. https://doi.org/10.1016/i.ijmm.2013.09.003

Dosler, S., \& Gerceker, A. A. (2011). In vitro activities of nisin alone or in combination with vancomycin and ciprofloxacin against methicillin-resistant and methicillin-susceptible Staphylococcus aureus strains. Chemotherapy, 57(6), 511516. https://doi.org/10.1159/000335598

Dufour, A., Hindré, T., Haras, D., \& Le Pennec, J. P. (2007). The biology of lantibiotics from the lacticin 481 group is coming of age. FEMS microbiology reviews, 31(2), 134-167. https://doi.org/10.1111/j.1574-6976.2006.00045.x

Farkas-Himsley H. (1980). Bacteriocins--are they broad-spectrum antibiotics?. The Journal of antimicrobial chemotherapy, 6(4), 424-426 https://doi.org/10.1093/jac/6.4.424

Field, D., Gaudin, N., Lyons, F., O'Connor, P. M., Cotter, P. D., Hill, C., \& Ross R. P. (2015). A bioengineered nisin derivative to control biofilms of Staphylococcus pseudintermedius. PloS one, 10(3), e0119684. https://doi.org/10.1371/journal.pone.0119684

Galvin, M., Hill, C., \& Ross, R. P. (1999). Lacticin 3147 displays activity in buffer against gram-positive bacterial pathogens which appear insensitive in standard plate assays. Letters in applied microbiology, 28(5), 355-358. https://doi.org/10.1046/j.1365-2672.1999.00550.x

Garde, S., Avila. M., Fernandez-Garcia. E., Medina. M., \& Nunez M. (2007) Volatile compounds and aroma of Hispánico cheese manufactured using lacticin 481-producing Lactococcus lactis subsp. lactis INIA 639 as an adjunct culture. International Dairy Journal, 17(6):717-726. DOI: 10.1016/j.idairyj.2006.07.005.

Georgalaki, M., Papadelli, M., Chassioti, E., Anastasiou, R., Aktypis, A., De Vuyst, L., Van Driessche, G., Devreese, B., \& Tsakalidou, E. (2010). Milk protein fragments induce the biosynthesis of macedocin, the lantibiotic produced by Streptococcus macedonicus ACA-DC 198. Applied and environmental microbiology, 76(4), 1143-1151. https://doi.org/10.1128/AEM.00151-09

Georgalaki, M., Papadimitriou, K., Anastasiou, R., Pot, B., Van Driessche, G. Devreese, B., \& Tsakalidou, E. (2013). Macedovicin, the second food-grade lantibiotic produced by Streptococcus macedonicus ACA-DC 198. Food microbiology, 33(1), 124-130. https://doi.org/10.1016/j.fm.2012.09.008

Gilmore, M. S., Segarra, R. A., Booth, M. C., Bogie, C. P., Hall, L. R., \& Clewell, D. B. (1994). Genetic structure of the Enterococcus faecalis plasmid pAD1encoded cytolytic toxin system and its relationship to lantibiotic determinants. Journal of bacteriology, 176(23), 7335-7344. https://doi.org/10.1128/jb.176.23.7335-7344.1994

Gomes, K. M., Duarte, R. S., \& de Freire Bastos, M. (2017). Lantibiotics produced by Actinobacteria and their potential applications (a review). Microbiology (Reading, England), 163(2), 109-121. https://doi.org/10.1099/mic.0.000397 González, B., Arca, P., Mayo, B., \& Suárez, J. E. (1994). Detection, purification, and partial characterization of plantaricin $\mathrm{C}$, a bacteriocin produced by a Lactobacillus plantarum strain of dairy origin. Applied and environmental microbiology, 60(6), 2158-2163. https://doi.org/10.1128/AEM.60.6.21582163.1994

Gross, E. \& Morell, J. L. (1971). The structure of nisin. Journal of the American Chemical Society, 93(18), 4634-4635. https://doi.org/10.1021/ja00747a073 Guder, A., Wiedemann, I., \& Sahl, H. G. (2000). Posttranslationally modified bacteriocins--the lantibiotics. Biopolymers, 55(1), $62-73$ https://doi.org/10.1002/1097-0282(2000)55:1<62::AID-BIP60>3.0.CO;2-Y Guinane, C. M., Cotter, P. D., Hill, C., \& Ross, R. P. (2005). Microbial solutions to microbial problems; lactococcal bacteriocins for the control of undesirable biota in food. Journal of applied microbiology,98(6), 1316-1325. https://doi.org/10.1111/j.1365-2672.2005.02552.x 
Gul, S., Masud, T., Maqsood, S., Latif, A., Irshad, I., \& ul Haque, I. (2012) Streptococcus thermophilus bacteriocin, from production to their application: An overview. African Journal of Microbiology Research, 6, 859-866.

Hasper, H. E., Kramer, N. E., Smith, J. L., Hillman, J. D., Zachariah, C., Kuipers, O. P., de Kruijff, B., \& Breukink, E. (2006). An alternative bactericidal mechanism of action for lantibiotic peptides that target lipid II. Science (New York, N.Y.), 313(5793), 1636-1637. https://doi.org/10.1126/science.1129818

Holo, H., Jeknic, Z., Daeschel, M., Stevanovic, S., \& Nes, I. F. (2001). Plantaricin W from Lactobacillus plantarum belongs to a new family of two-peptide lantibiotics. Microbiology (Reading, England), 147( $\mathrm{Pt} \quad 3), \quad 643-651$. https://doi.org/10.1099/00221287-147-3-643

Iannitti, T., \& Palmieri, B. (2010). Therapeutical use of probiotic formulations in clinical practice. Clinical nutrition (Edinburgh, Scotland), 29(6), 701-725. https://doi.org/10.1016/j.clnu.2010.05.004

Ingram L. C. (1969). Synthesis of the antibiotic nisin: formation of lanthionine and beta-methyl-lanthionine. Biochimica et biophysica acta, 184(1), 216-219. https://doi.org/10.1016/0304-4165(69)90121-4

Joo, N. E., Ritchie, K., Kamarajan, P., Miao, D., \& Kapila, Y. L. (2012). Nisin, an apoptogenic bacteriocin and food preservative, attenuates HNSCC tumorigenesis via CHAC1. Cancer medicine, 1(3), 295-305. https://doi.org/10.1002/cam4.35

Lawton, E. M., Ross, R. P., Hill, C., \& Cotter, P. D. (2007). Two-peptide lantibiotics: a medical perspective. Mini reviews in medicinal chemistry, 7(12), 1236-1247. https://doi.org/10.2174/138955707782795638

Leroy, F., \& De Vuyst, L. (2010). Bacteriocins of lactic acid bacteria to combat undesirable bacteria in dairy products. Australian Journal of Dairy Technology, 65(3), 143-149.

Liu, W., \& Hansen, J. N. (1990). Some chemical and physical properties of nisin, a small-protein antibiotic produced by Lactococcus lactis. Applied and environmental microbiology, 56(8),

2551-2558 https://doi.org/10.1128/AEM.56.8.2551-2558.1990

Lombardi, A., Gatti, M., Rizzotti, L., Torriani, S., Andrighetto, C., \& Giraffa G. (2004). Characterization of Streptococcus macedonicus strains isolated from artisanal Italian raw milk cheeses. International Dairy Journal, 14(11), 967-976. https://doi.org/10.1016/j.idairyj.2004.04.005

Lubelski, J., Rink, R., Khusainov, R., Moll, G. N., \& Kuipers, O. P. (2008) Biosynthesis, immunity, regulation, mode of action and engineering of the mode lantibiotic nisin. Cellular and molecular life sciences : CMLS, 65(3), 455-476. https://doi.org/10.1007/s00018-007-7171-2

Martínez-Cuesta, M.C., Bengoechea, J., Bustos, I., Rodríguez, B., Requena, T., \& Peláez, C. (2010). Control of late blowing in cheese by adding lacticin 3147producing Lactococcus lactis IFPL 3593 to the starter. International Dairy Journal, 20, 18-24. 10.1016/j.idairyj.2009.07.005.

Małaczewska, J, Kaczorek-Łukowska E. (2021) Nisin-A lantibiotic with immunomodulatory properties: A review. Peptides.;137:170479. doi 10.1016/j.peptides.2020.170479.

McAuliffe, O., Ross, R. P., \& Hill, C. (2001). Lantibiotics: structure, biosynthesis and mode of action. FEMS microbiology reviews, 25(3), 285-308 https://doi.org/10.1111/j.1574-6976.2001.tb00579.x

Millette, M., Cornut, G., Dupont, C., Shareck, F., Archambault, D., \& Lacroix, M (2008). Capacity of human nisin- and pediocin-producing lactic acid bacteria to reduce intestinal colonization by vancomycin-resistant Enterococci. Applied and environmental microbiology, 74, 1997-2003. 10.1128/AEM.02150-07.

Morgan, S. M., Galvin, M., Ross, R. P., \& Hill, C. (2001). Evaluation of a spraydried lacticin 3147 powder for the control of Listeria monocytogenes and Bacillus cereus in a range of food systems. Letters in applied microbiology, 33(5), 387 391. https://doi.org/10.1046/j.1472-765x.2001.01016.x

Morgan, S. M., O'connor, P. M., Cotter, P. D., Ross, R. P., \& Hill, C. (2005) Sequential actions of the two component peptides of the lantibiotic lacticin 3147 explain its antimicrobial activity at nanomolar concentrations. Antimicrobia agents and chemotherapy, 49(7), 2606-2611. https://doi.org/10.1128/AAC.49.7.2606-2611.2005

Mulders, J. W., Boerrigter, I. J., Rollema, H. S., Siezen, R. J., \& de Vos, W. M. (1991). Identification and characterization of the lantibiotic nisin Z, a natural nisin variant. European journal of biochemistry, 201(3), 581-584 https://doi.org/10.1111/j.1432-1033.1991.tb16317.x

Nes, I. F., \& Tagg, J. R. (1996). Novel lantibiotics and their pre-peptides. Antonie van Leeuwenhoek, 69(2), 89-97. https://doi.org/10.1007/BF00399414

Nes, I. F., Diep, D. B., \& Ike, Y. (2014). Enterococcal bacteriocins and antimicrobial proteins that contribute to niche control in Enterococci: From commensals to leading causes of drug resistant infection, eds M. Gilmore, D. Clewell, Y. Ike, and N. Shankar (Boston, MA: Massachusetts Eye and Ear Infirmary).

O’Sullivan, L., Ross, R.P., \& Hill C. (2003). A lacticin 481-producing adjunct culture increases starter lysis while inhibiting nonstarter lactic acid bacteria proliferation during Cheddar cheese ripening. Journal of Applied Microbiology, 95(6), 1235-1241.

Okuda K, Zendo T, Sugimoto S, et al. Effects of bacteriocins on methicillinresistant Staphylococcus aureus biofilm. Antimicrob Agents Chemother. 2013;57(11):5572-5579. doi:10.1128/AAC.00888-13
Ortolani, M. B., Moraes, P. M., Perin, L. M., Viçosa, G. N., Carvalho, K. G., Silva Júnior, A., \& Nero, L. A. (2010). Molecular identification of naturally occurring bacteriocinogenic and bacteriocinogenic-like lactic acid bacteria in raw milk and soft cheese. Journal of dairy science, 93(7), 2880-2886 https://doi.org/10.3168/jds.2009-3000

O'Sullivan, L., O'connor, E. B., Ross, R. P., \& Hill, C. (2006). Evaluation of liveculture-producing lacticin 3147 as a treatment for the control of Listeria monocytogenes on the surface of smear-ripened cheese. Journal of applied microbiology, 100(1), 135-143. $\quad$ https://doi.org/10.1111/j.13652672.2005.02747.x

Papadelli, M, Karsioti,A., Anastasiou, R., Georgalaki, M., \& Tsakalidou, E.(2007) Characterization of the gene cluster involved in the biosynthesis of macedocin, the lantibiotic produced by Streptococcus macedonicus, FEMS Microbiology Letters, 272(1), 75-82, 10.1111/j.1574-6968.2007.00740.x

Parapouli, M., Delbès-Paus, C., Kakouri, A., Koukkou, A. I., Montel, M. C., \& Samelis, J. (2013). Characterization of a wild, novel nisin a-producing Lactococcus strain with an L. lactis subsp. cremoris genotype and an L. lactis subsp. lactis phenotype, isolated from Greek raw milk. Applied and environmental microbiology, 79(11), 3476-3484. https://doi.org/10.1128/AEM.00436-13

Perin, L.M., Moraes, P.M., Viçosa, G.N., Silva, Júnior A., \& Nero L.A. (2012). Identification of bacteriocinogenic Lactococcus isolates from raw milk and cheese capable of producing nisin A and nisin Z. International Dairy Journal, 25(1), 46 51. 10.1016/j.idairyj.2011.12.010

Piard JC, Kuipers OP, Rollema HS, Desmazeaud MJ, de Vos WM. Structure, organization, and expression of the lct gene for lacticin 481, a novel lantibiotic produced by Lactococcus lactis. J Biol Chem. 1993;268(22):16361-16368.

Piper, C., Cotter, P. D., Ross, R. P., \& Hill, C. (2009). Discovery of medically significant lantibiotics. Current drug discovery technologies, 6(1), 1-18 https://doi.org/10.2174/157016309787581075

Piper, C., Draper, L. A., Cotter, P. D., Ross, R. P., \& Hill, C. (2009). A comparison of the activities of lacticin 3147 and nisin against drug-resistant Staphylococcus aureus and Enterococcus species. The Journal of antimicrobial chemotherapy, 64(3), 546-551. https://doi.org/10.1093/jac/dkp221

Quigley, L., O'Sullivan, O., Beresford, T. P., Ross, R. P., Fitzgerald, G. F., \& Cotter, P. D. (2012). High-throughput sequencing for detection of subpopulations of bacteria not previously associated with artisanal cheeses. Applied and environmental microbiology, 78(16),

$5717-5723$

https://doi.org/10.1128/AEM.00918-12

Rodriguez, E., Arques, J. L., Nuñez, M., Gaya, P., \& Medina, M. (2005) Combined effect of high-pressure treatments and bacteriocin-producing lactic acid bacteria on inactivation of Escherichia coli O157:H7 in raw-milk cheese. Applied and environmental microbiology, 71(7)

3399-3404. https://doi.org/10.1128/AEM.71.7.3399-3404.2005

Rodríguez, Eva., Gonzalez, B., Gaya, P., Nuñez, M., \& Medina, M. (2000) Diversity of bacteriocins produced by lactic acid bacteria isoated from raw milk International Dairy Journal, 10(1-2), 7-15. 10.1016/S0958-6946(00)00017-0.

Rogers, L. A., \& Whittier, E. O. (1928). LIMITING FACTORS IN THE LACTIC FERMENTATION. Journal of bacteriology, 16(4), 211-229. https://doi.org/10.1128/JB.16.4.211-229.1928

Rollema, H. S., Metzger, J. W., Both, P., Kuipers, O. P., \& Siezen, R. J. (1996) Structure and biological activity of chemically modified nisin A species. European journal of biochemistry,241(3), 716-722. https://doi.org/10.1111/j.1432 1033.1996.00716.x

Ryan, M. P., Jack, R. W., Josten, M., Sahl, H. G., Jung, G., Ross, R. P., \& Hill, C. (1999). Extensive post-translational modification, including serine to D-alanine conversion, in the two-component lantibiotic, lacticin 3147. The Journal of biological chemistry, 274(53)

$37544-37550$

https://doi.org/10.1074/jbc.274.53.37544

Ryan, M. P., Rea, M. C., Hill, C., \& Ross, R. P. (1996). An application in cheddar cheese manufacture for a strain of Lactococcus lactis producing a novel broadspectrum bacteriocin, lacticin 3147. Applied and environmental microbiology, 62(2), 612-619. https://doi.org/10.1128/AEM.62.2.612-619.1996

Sahl, H. G., Jack, R. W., \& Bierbaum, G. (1995). Biosynthesis and biological activities of lantibiotics with unique post-translational modifications. European journal of biochemistry,230(3), 827-853. https://doi.org/10.1111/j.1432 1033.1995.tb20627.x

Sahl, H., \& Bierbaum, G. (2008). Multiple Activities in Natural Antimicrobials Microbe Magazine, 3(10), 467-473. 10.1128/microbe.3.467.

Samelis, J., Kakouri, A., Rogga, K.J., Savvaidis, I.N., \& Kontominas, M.G. (2003) Nisin treatments to control Listeria monocytogenes post-processing contamination on Anthotyros, a traditional Greek whey cheese, stored at $4{ }^{\circ} \mathrm{C}$ in vacuum packages Food Microbiology, 20(6), 661-669. http://dx.doi.org/10.1016\%2FS0740 0020(03)00018-2

Severina, E., Severin, A., \& Tomasz, A. (1998). Antibacterial efficacy of nisin against multidrug-resistant Gram-positive pathogens. The Journal of antimicrobial chemotherapy, 41(3), 341-347. https://doi.org/10.1093/jac/41.3.341

Shin, J. M., Ateia, I., Paulus, J. R., Liu, H., Fenno, J. C., Rickard, A. H., \& Kapila,

Y. L. (2015). Antimicrobial nisin acts against saliva derived multi-species biofilms 
without cytotoxicity to human oral cells. Frontiers in microbiology, 6, 617. https://doi.org/10.3389/fmicb.2015.00617

Shin, J. M., Gwak, J. W., Kamarajan, P., Fenno, J. C., Rickard, A. H., \& Kapila, Y. L. (2016). Biomedical applications of nisin. Journal of applied microbiology, 120(6), 1449-1465. https://doi.org/10.1111/jam.13033

Siezen, R. J., Kuipers, O. P., \& de Vos, W. M. (1996). Comparison of lantibiotic gene clusters and encoded proteins. Antonie van Leeuwenhoek, 69(2), 171-184. https://doi.org/10.1007/BF00399422

Singh, A. P., Prabha, V., \& Rishi, P. (2013). Value addition in the efficacy of conventional antibiotics by Nisin against Salmonella. PloS one, 8(10), e76844. https://doi.org/10.1371/journal.pone.0076844

Sobrino-López, A., \& Martín-Belloso, O. (2008). Use of nisin and other bacteriocins for preservation of dairy products. International Dairy Journal, 18(4), 329-343. DOI: 10.1016/j.idairyj.2007.11.009

Thomas, L.V., \& Delves-Broughton, J. (2001). New advances in the application of the food preservative nisin. Research Advances in Food Science, 2, 11-22.

Thuault, D., Beliard, E., Le Guern, J., \& Bourgeois, C. M. (1991). Inhibition of Clostridium tyrobutyricum by bacteriocin-like substances produced by lactic acid bacteria. Journal of dairy science, 74(4), 1145-1150 https://doi.org/10.3168/jds.S0022-0302(91)78266-0

Todorov S. D. (2008). Bacteriocin production by Lactobacillus plantarum AMA$\mathrm{K}$ isolated from Amasi, a Zimbabwean fermented milk product and study of the adsorption of bacteriocin AMA-K TO Listeria sp. Brazilian journal of microbiology : [publication of the Brazilian Society for Microbiology], 39(1), 178-187. https://doi.org/10.1590/S1517-838220080001000035

Todorov S. D. (2009). Bacteriocins from Lactobacillus plantarum - production, genetic organization and mode of action: produção, organização genética e modo de ação. Brazilian journal of microbiology : [publication of the Brazilian Society for Microbiology], 40(2), 209-221. https://doi.org/10.1590/S1517 83822009000200001

Tong, Z., Dong, L., Zhou, L., Tao, R., \& Ni, L. (2010). Nisin inhibits dental cariesassociated microorganism in vitro. Peptides, 31(11), 2003-2008 https://doi.org/10.1016/j.peptides.2010.07.016

Turner, D. L., Brennan, L., Meyer, H. E., Lohaus, C., Siethoff, C., Costa, H. S., Gonzalez, B., Santos, H., \& Suárez, J. E. (1999). Solution structure of plantaricin C, a novel lantibiotic. European journal of biochemistry, 264(3), 833-839. https://doi.org/10.1046/j.1432-1327.1999.00674.x

Vacheyrou, M., Normand, A. C., Guyot, P., Cassagne, C., Piarroux, R., \& Bouton, Y. (2011). Cultivable microbial communities in raw cow milk and potential transfers from stables of sixteen French farms. International journal of food microbiology, 146(3),

253-262.

https://doi.org/10.1016/i.ijfoodmicro.2011.02.033

van den Hooven, H. W., Lagerwerf, F. M., Heerma, W., Haverkamp, J., Piard, J. C., Hilbers, C. W., Siezen, R. J., Kuipers, O. P., \& Rollema, H. S. (1996). The structure of the lantibiotic lacticin 481 produced by Lactococcus lactis: location of the thioether bridges. FEBS letters, 391(3), 317-322. https://doi.org/10.1016/0014-5793(96)00771-5

van Heusden, H. E., de Kruijff, B., \& Breukink, E. (2002). Lipid II induces a transmembrane orientation of the pore-forming peptide lantibiotic nisin. Biochemistry, 41(40), 12171-12178. https://doi.org/10.1021/bi026090x

van Kraaij, C., Breukink, E., Rollema, H. S., Bongers, R. S., Kosters, H. A., de Kruijff, B., \& Kuipers, O. P. (2000). Engineering a disulfide bond and free thiols in the lantibiotic nisin Z. European journal of biochemistry, 267(3), 901-909. https://doi.org/10.1046/j.1432-1327.2000.01075.x

Wiedemann, I., Benz, R., \& Sahl, H. G. (2004). Lipid II-mediated pore formation by the peptide antibiotic nisin: a black lipid membrane study. Journal of bacteriology, 186(10), 3259-3261. https://doi.org/10.1128/jb.186.10.32593261.2004

Wiedemann, I., Breukink, E., van Kraaij, C., Kuipers, O. P., Bierbaum, G., de Kruijff, B., \& Sahl, H. G. (2001). Specific binding of nisin to the peptidoglycan precursor lipid II combines pore formation and inhibition of cell wall biosynthesis for potent antibiotic activity. The Journal of biological chemistry, 276(3), 17721779. https://doi.org/10.1074/jbc.M006770200

Willey, J. M., \& Gaskell, A. A. (2011). Morphogenetic signaling molecules of the streptomycetes. Chemical reviews, 111(1), 174-187. https://doi.org/10.1021/cr1000404

Willey, J. M., \& van der Donk, W. A. (2007). Lantibiotics: peptides of diverse structure and function. Annual review of microbiology, 61, 477-501. https://doi.org/10.1146/annurev.micro.61.080706.093501

Wu, J., Hu, S., \& Cao, L. (2007). Therapeutic effect of nisin Z on subclinical mastitis in lactating cows. Antimicrobial agents and chemotherapy, 51(9), 31313135. https://doi.org/10.1128/AAC.00629-07

Xiao, H., Chen, X., Chen, M., Tang, S., Zhao, X., \& Huan, L. (2004). Bovicin HJ50, a novel lantibiotic produced by Streptococcus bovis HJ50. Microbiology (Reading, England), 150(Pt 1), 103-108. https://doi.org/10.1099/mic.0.26437-0 